indicator "age of sexual consent", the prospects of conducting interdisciplinary researches look as promising.

It has been established that Art. 152 and Art. 153 of the Criminal Code of Ukraine, updated in accordance with the Istanbul Convention, although they embody the concept of "age of sexual consent", do not take into account the requirement of part 3 of Art. 18 of the Lanzarote Convention on the impact of the difference in the age of participants in such activities on criminal liability for Sexual Activities.

The prospects for the "age of sexual consent" in Ukraine as an autonomous (in the absence of voluntary consent) criteria for determining the limits of criminal behavior in the sexual sphere have been determined.

As an option, Section IV of the Special Part of the Criminal Code of Ukraine could be supplemented by a separate prohibition on committing acts of sexual nature involving persons, who have not reached the "age of sexual consent". This prohibition should cover not only actions of the perpetrator (that is, his active behavior towards the victim), but also the perpetrator's consent to the victimized child to commit sexual acts in relation to himself, as well as forcing the child to commit sexual acts with the third person. This defect of this option is seen in the fact that it runs counter to the idea of the Istanbul Convention on the universal role in the normalization of the limits of criminal behavior in the sexual sphere of such factor as the lack of voluntary consent.

An alternative approach, based on the priority of the Istanbul Convention, is to reject the direct (textual) reflection in the Criminal Code of Ukraine of the "age of sexual consent" concept. The issue of criminal liability for committing sexual acts involving children is proposed through the prism of the universal conventional understanding of voluntary consent by assessing the actual circumstances in a particular criminal proceeding, that is, within the specified Articles 152, 153 of the Criminal Code of Ukraine, on sexual violence. In other words, the role of a crime-forming feature, in this case, will not be achieved by the victim reaching a certain age defined by law, but by the absence of the victim's voluntary consent, as is characteristic of sexual violence in the meaning of the Istanbul Convention.

Key words: age, voluntary consent, sexual abuse, helpless state, minor, puberty, child.

УДК 343.131 .5

Дульсъкий О.Л.

аспірант кафедри досудового розслідування Навчальнонаукового інституту № 1 Національної академії внутрішніх справ, адвокат (м. Харків, Украӥна)

\title{
ЗАХИСНИК ЯК УЧАСНИК ПРОВЕДЕННЯ ОБШУКУ
}

У статті розглянуто суперечливі питання участі захисника та адвоката під час проведення обшуку житла чи іншого володіння особи та обшуку особи. Акцентовано увагу на низку положень, спрямованих на забезпечення дотримання прав та законних інтересів учасників обшуку. Висловлено низку пропозицій щодо вдосконалення чинного Кримінального процесуального кодексу України в частині процесуального врегулювання діяльності захисникаадвоката з надання юридичної допомоги особі під час проведення обшуку.

Ключові слова: слідчі (розшукові) дії, обшук житла чи іншого володіння особи, обшук особи, захисник, адвокат, підозрюваний, інший учасник кримінального провадження.

(С) Дульський О. Л., 2019 
Постановка проблеми. У КПК Украӥни передбачено досить широке, хоча й невичерпне, коло учасників обшуку. До них відповідно до частини 1 статті 236 КПК України належать потерпілий, підозрюваний, захисник, представник, спеціаліст, особа, чиї права та законні інтереси може бути обмежено або порушено. Обшук житла чи іншого володіння особи, обшук особи, як зазначено в абзаці другому частини 7 статті 223 цього Кодексу, здійснюють 3 обов'язковою участю не менше двох понятих незалежно від застосування технічних засобів їх фіксування.

Усіх учасників обшуку треба розглядати з урахуванням їх статусу як сторони кримінального провадження, виду обшуку, можливості ініціювання його проведення, обов'язковості або факультативності їх залучення, місця й ролі в доказуванні та здійснюваних ними функцій. Такі критерії сприятимуть ліпшому розумінню особливостей забезпечення дотримання прав та законних інтересів осіб, які в тій чи іншій якості беруть участь у проведенні обшуку. Усіх зазначених осіб, на наш погляд, доцільно поділити на дві групи: 1) осіб, діяльність яких спрямована на швидке та якісне проведення обшуку, відшукання та вилучення матеріальних об'єктів для їх використання в доказуванні; 2) осіб, які потребують забезпечення дотримання їх прав та законних інтересів під час проведення обшуку. Саме процесуальна діяльність представників другої групи учасників, особливе місце серед яких належить захисникові, викликає нашу найбільшу зацікавленість, оскільки проведення обшуку практично завжди пов'язане із суттевим обмеженням їх конституційного права на недоторканність житла чи іншого володіння особи.

Аналіз останніх досліджень і публікацій. Після набрання чинності КПК України окремі аспекти забезпечення дотримання прав та законних інтересів учасників обшуку, зокрема захисником, досліджували В. Ю. Аббакумов, В. І. Галаган, О. В. Капліна, Е. Є. Манівлець, Н. С. Моргун, М. А. Погорецький, О. А. Струць, В. М. Трофименко, О.Г.Шило та інші науковці. Але досі залишається невирішеною значна кількість проблем у цьому напрямі, які потребують усвідомлення, аналізу та вирішення на законодавчому рівні й у практичній діяльності з розслідування злочинів.

Формування цілей. Автор має на меті дослідити процесуальні повноваження захисника як сторони захисту й процесуального учасника, який забезпечує дотримання прав та законних інтересів інших осіб під час проведення обшуку як заходу процесуального примусу.

Виклад основного матеріалу. Поза сумнівом, центральною фігурою сторони захисту є захисник - адвокат як професійно підготовлена особа, який має відповідно до закону широке коло повноважень із забезпечення прав та законних інтересів фізичних та юридичних осіб у кримінальному провадженні. Тож цілком логічно, що розгляд проблемних питань правового регулювання діяльності сторони захисту під час проведення обшуку за чинним законодавством України варто починати саме 3 аналізу процесуальної діяльності захисника.

У практичній діяльності захисника-адвоката існують два проблемних аспекти його участі під час проведення обшуку. Перший має місце тоді, коли 
йдеться про допуск до участі в проведенні обшуку житла чи іншого володіння особи адвоката як захисника підозрюваного, який уже має в кримінальному провадженні визначений процесуальний статус і потребує кваліфікованої юридичної допомоги та захисту від підозри. Другий аспект стосується адвоката під час надання правової допомоги особі, яка до певного часу не має процесуального статусу в кримінальному провадженні. Адже непоодинокими є випадки, коли існує потреба проведення обшуку житла чи іншого володіння особи в членів сім'ї, співмешканців підозрюваного або в осіб, які є власниками вилученого під час обшуку майна.

Процесуальний статус захисника, як і інших учасників кримінального провадження, виникає з моменту залучення його до сфери кримінальних процесуальних правовідносин, урегульованих КПК України, Законами України «Про адвокатуру та адвокатську діяльність», «Про безоплатну правову допомогу» тощо. У науковій літературі цілком слушно зазначено, що саме у сфері кримінального судочинства найчастіше трапляються різноманітні порушення прав людини, на стороні якої стоїть адвокат. У таких справах на кону стоять дуже вагомі речі, тому захист не може бути довірений неспеціалісту [1, с. 13].

Інші науковці, приділяючи увагу статусу саме адвоката, визнають, що єдиною, головною відмінністю адвокатури як суб'єкта надання правової допомоги є власний адвокатський статус, тобто сукупність передбачених законом прав, обов'язків і гарантій адвокатської діяльності [2, с. 12-16]. Погоджуємося, що цей особливий статус покликаний забезпечити ефективність правової допомоги адвоката порівняно з юридичними послугами, що надають в Україні інші суб'єкти. Водночас особливістю кримінального провадження $\epsilon$ те, що особа, будучи адвокатом за посадою, може в різних випадках виступати і як захисник, і як, власне, адвокат.

На захисників-адвокатів покладається обов'язок забезпечити захист особи й надання їй потрібної правової допомоги, у низці випадків безоплатної. Незважаючи на законодавче закріплення зазначеного положення, у науці точиться дискусія щодо визначення поняття та правового статусу осіб, які реалізують право на правову допомогу в кримінальному провадженні. Ще до прийняття чинного КПК України Р. А. Чайка цілком слушно зауважував, що варто розрізняти поняття «захисник» і «адвокат». На думку цього науковця, адвокат - це особа, яка займається професійною діяльністю, тобто $є$ правозаступником i правозахисником та надає правову допомогу, здійснює представництво в судах, господарських справах, підприємствах, установах та організаціях, державних органах, а також здійснює захист підозрюваного, обвинуваченого. Правовий статус адвоката виникає не у зв'язку з його участю в судочинстві, а через відповідну процедуру, яка передбачена законодавством України. Натомість захисник у кримінальному провадженні, продовжує далі зазначений автор,- це особа, спеціально уповноважена відстоювати законні інтереси обвинуваченого, підсудного й надає йому необхідну правову допомогу в реалізації його процесуальних прав. 
Процесуальним статусом ця особа наділена з моменту допуску до участі в справі [3, с. 15]. На думку О. В. Мартовицької, 3 якою не можна не погодитися, незважаючи на те, що в статті 45 КПК України визначено, що особа, яка реалізує право на правову допомогу, іменується захисником, який $\epsilon$ адвокатом, утім підняті питання не є остаточними й потребують окремого дослідження або наукового вивчення [4, с. 294-296].

Тож не можна не погодитися 3 думкою, що поняття «захисник» та «адвокат» не є тотожними. Зокрема, під час захисту підозрюваного адвокат за посадою є захисником цих осіб за своїм процесуальним статусом. Натомість, надаючи юридичну допомогу потерпілому, адвокат за посадою $є$ його представником за процесуальним статусом відповідно до частини 1 статті 58 КПК України. Щодо свідка чи іншого учасника кримінального провадження, крім підозрюваного, обвинуваченого, ця особа є адвокатом як за посадою, так і за процесуальним статусом (див., наприклад: пункт 2 частини 1 статті 66, частина 3 статті 236 КПК України). Власне, опосередковано про цю відмінність ідеться й у низці норм КПК України. Зокрема, у частині 1 статті 236 цього Кодексу, що унормовує процесуальні аспекти проведення обшуку, зазначено, що незалежно від стадії цієї слідчої дії слідчий, прокурор, інша службова особа, яка бере участь у проведенні обшуку, зобов'язані допустити на місце його проведення захисника чи адвоката (курсив нам О. Д.), повноваження якого підтверджуються згідно з положеннями статті 50 цього Кодексу [5]. Розглянемо детальніше різницю в процесуальному статусі цих осіб.

Захисник-адвокат відповідно до частини 4 статті 46, частин 1, 2 статті 50 КПК України здійснює захист підозрюваного (обвинуваченого) i користується процесуальними правами особи, захист якої він здійснює, крім процесуальних прав, реалізація яких здійснюється безпосередньо підозрюваним, обвинуваченим і не може бути доручена захисникові, 3 моменту надання передбачених цим Кодексом документів: свідоцтва про право на зайняття адвокатською діяльністю; ордера, договору із захисником або доручення органу (установи), уповноваженого законом на надання безоплатної правової допомоги. Установлення будь-яких додаткових вимог, крім пред'явлення захисником документа, що посвідчує його особу, або умов для підтвердження повноважень захисника чи для його залучення, до участі в кримінальному провадженні не допускається (частина 2 статті 50 КПК України).

Отже, захисник як учасник обшуку може бути присутнім під час проведення обшуку за участю підозрюваного або без нього; ознайомлюватися 3 протоколом обшуку, з документами, які були пред'явлені або мали бути пред'явлені підозрюваному; оскаржувати дії та рішення слідчого й прокурора. Проте, на наш погляд, законодавством не врегульовано питання забезпечення участі захисника під час проведення одночасних обшуків у декількох підозрюваних осіб, функцію захисту яких здійснює один адвокат, хоча $з$ погляду криміналістичної тактики такі обшуки є найбільш дієвими та ефективними. 
Під час проведення обшуку особи, що нерідко супроводжується іï оголенням, відкритим залишене питання, як треба вчинити, якщо захисник цієї особи іншої статі, ніж його підзахисний. В абзаці другому частини 5 статті 236 КПК України лише зазначено, що обшук особи здійснюється особами тієї самої статі в присутності адвоката, представника на вимогу такої особи. Конструкція цієї правової норми, а також відсутність імперативної вказівки про те, що захисник та його підзахисна особа мають бути однієї статі, надають підстави стверджувати, що їх стать не має значення під час реалізації функції захисту від підозри. Підтверджує цю думку й наявна вимога особи перед ії обшуком запросити захисника, стать якого йому добре відома за наявності між ними договору на надання юридичних послуг.

Водночас звертає на себе увагу та обставина, що в частині 1 статті 236 КПК України йдеться про допуск захисника чи адвоката на місце проведення обшуку, а в частині 5 цієї ж процесуальної норми - лише про присутність адвоката під час обшуку особи. Але ж обшук може бути проведено в осіб, які є підозрюваними, і тоді їхній захист здійснює захисникадвокат. Якщо ж у житлі чи іншому володінні перебуває особа, яка не є підозрюваною, але стосовно якої існує потреба проведення обшуку, юридичну допомогу ӥй надає саме адвокат, про якого, власне, ідеться в частині 5 статті 236 КПК України. Для усунення цієї невідповідності пропонуємо перше речення абзацу другого частини 5 цього Кодексу викласти в такій редакції: «Обшук особи здійснюють особи тієї самої статі в присутності захисника, адвоката чи представника на вимогу такої особи». Урахування цієї пропозиції узгоджуватиметься 3 положеннями частини 1 статті 236 КПК України та сприятиме однаковому тлумаченню випадків, коли на місце проведення обшуку має бути допущений захисник, а коли - адвокат.

Однак наразі в КПК України не повною мірою закріплено права особи, у якої проводять обшук, якщо вона не є підозрюваним або законним представником (наприклад, орендодавець). Такій особі надане право бути присутньою під час усіх дій слідчого й робити заяви з цього приводу. Але потрібно в КПК України розширити права цієї особи для захисту своїх прав і законних інтересів (наприклад, заявляти відвід, подавати скаргу, клопотати про участь захисника тощо).

Відповідно до частини 5 статті 46 КПК України захисник має право брати участь у проведенні процесуальних дій за участі підозрюваного. Тож за логікою речей у цьому випадку в слідчого має бути обов' язок повідомляти захисника про проведення цих дій. Проте в КПК України відсутня ця зобов'язувальна норма. На наше переконання, недостатньо лише надати право учасникові кримінального провадження, треба ще створити спеціальні нормативні й організаційні засоби, здатні гарантувати як здійснення цих прав і реалізацію законних інтересів, так і захист їх від безпідставного ускладнення, а часом і від прямого порушення. У зв'язку 3 викладеним пропонуємо доповнити частину 5 статті 46 КПК України третім реченням такого змісту: «За наявності клопотання підозрюваного чи його захисника, слідчий зобов'язаний завчасно повідомляти захисника про всі подальші 
процесуальні дії за участі підозрюваного». У цьому випадку захисник підозрюваного матиме реальну можливість самому вирішувати потребу прибуття для участі в проведенні процесуальних дій зі своєю підзахисною особою.

Захисник-адвокат, так само як і його підзахисний, не є обов'язковим учасником проведення обшуку. Однак видається, що у випадку, якщо слідчий планує присутність підозрюваного під час проведення цієї процесуальної дії, він має після пред'явлення ухвали суду з'ясувати його думку щодо того, чи потрібен йому виклик захисника. Оскільки ініціатива такого виклику має виходити від обшукуваного, а спрогнозувати іï неможливо, слідчому залишається постійно бути готовим до відповідного клопотання. Адже забезпечення підозрюваному права на захист передбачає обов' язок слідчого надати можливість цій особі захищатися встановленими законом засобами та способами від порушення пї особистих і майнових прав. Тож відмова від участі захисника під час проведення обшуку, на нашу думку, має бути заявлена підозрюваним добровільно, у зрозумілій для всіх присутніх учасників обшуку формі. Підкреслює добровільність такої відмови й обов'язкова фіксація проведення обшуку на підставі ухвали слідчого судді за допомогою звуко- та відеозаписувальних технічних засобів. Бажано було б також власноручно зафіксувати відмову в протоколі обшуку, хоча це положення в статті 236 КПК України наразі не передбачено.

У разі, якщо підозрюваний вимагає присутності адвоката під час проведення обшуку житла чи іншого володіння, перед слідчим постає завдання в стислі терміни забезпечити його участь. У ситуації, коли підозрюваний має захисника, допущеного до участі в кримінальному провадженні на законних підставах, слідчий сповіщає його про потребу невідкладно з'явитися на місце проведення обшуку. Водночас досі неврегульованим є питання щодо часу, протягом якого захисник має прибути на місце проведення обшуку. Якщо в абзаці другому частини 5 статті 236 КПК України зазначено, що неявка адвоката протягом трьох годин не перешкоджає проведенню обшуку особи, то час, потрібний для прибуття захисника-адвоката для участі в проведенні обшуку житла чи іншого володіння особи, у цьому Кодексі досі не визначений. Ця обставина не сприяє раптовості й оперативності проведення обшуку слідчим, однак не є підставою для порушення прав і законних інтересів обшукуваної особи. На наш погляд, у цьому разі варто виходити із засади розумності строків, відповідно до якої розумними вважаються строки, що є об'єктивно потрібними для виконання процесуальних дій та прийняття процесуальних рішень. Тож у цьому конкретному випадку строки, потрібні для прибуття захисника на місце проведення обшуку житла чи іншого володіння особи, мають бути визначені в кожному конкретному випадку залежно від низки обставин - місцевості та часу, потрібного для прибуття на місце проведення обшуку, можливості захисника невідкладно приїхати для участі в його проведенні тощо.

Якщо ж у підозрюваного на момент проведення обшуку немає захисника-адвоката або його присутність через низку причин неможлива, 
слідчий проводить обшук $з$ дотриманням належної правової процедури та обов'язкової його фіксації за допомогою звуко- та відеозаписувальних технічних засобів.

Безсумнівним позитивним фактором участі захисника під час проведення обшуку є те, що він може сприяти встановленню психологічного контакту слідчого з особами, яких обшукують, та запобіганню конфліктних ситуацій. Зокрема, захисник, який має авторитет у підозрюваного, членів його родини, може роз'яснити їм зміст події, що відбувається, підтвердити законність дій слідчого. В окремих випадках, під час проведення інших слідчих (розшукових) дій, адвокат, роз'ясняючи підозрюваному доказову значущість предметів (об'єктів), вилучених під час обшуку, може сприяти створенню нормальної психологічної обстановки й цим побічно сприяти досягненню мети розслідування при пом'якшуючих обставинах його проведення [6, с. 87-93].

Своєю чергою згідно з пунктом 3 частини 2 статті 87 КПК України порушення права підозрюваного на захист через недопущення адвоката до проведення обшуку є підставою визнання одержаних доказів недопустимими. Водночас факт недопущення до участі в проведенні обшуку зобов'язаний довести саме адвокат у суді під час судового провадження. Фізична перешкода захисникові в наданні ним правової допомоги своєму клієнтові, зокрема під час проведення обшуку, є злочином, передбаченим статтею 397 КК України (утручання в діяльність захисника чи представника особи), або статтею 398 КК України (заподіяння захисникові чи представникові особи тілесних ушкоджень у зв'язку з діяльністю, пов'язаною з наданням правової допомоги). Тож органи досудового розслідування не мають допускати створення штучних перешкод у професійній діяльності захисника, оскільки такі дії можуть призвести до притягнення до кримінальної відповідальності.

3 огляду на зазначене повною мірою погоджуємося 3 думкою авторів, що можливо й потрібно було б додати в КПК України пряму норму про обов'язок правоохоронних органів забезпечувати доступ адвоката до будьякого клієнта, зокрема й не сторони кримінального провадження, під час проведення обшуку належного йому приміщення [7].

В інших випадках відповідно до частини 3 статті 93 КПК України обшук може бути проведений за клопотанням адвоката як сторони захисту. До таких видів обшуку належить обшук житла чи іншого володіння особи та обшук особи. Дії захисника в цих випадках спрямовані на збирання доказів щодо меншої винуватості або невинуватості підзахисної йому особи, хоча повною мірою реалізувати своє право на участь у слідчих (розшукових) діях захисникові вдається не завжди. Прикладом такої реалізації є можливість захисника звернутися 3 клопотанням про надання дозволу на проведення обшуку в разі невиконання ухвали про тимчасовий доступ до речей i документів за його клопотанням як сторони захисту, якій надано право на доступ до речей і документів на підставі ухвали слідчого судді, але вона не була виконана. Якщо слідчим суддею надано дозвіл на проведення обшуку, його проведення доручається слідчому або прокуророві чи органу 
Національної поліції згідно з правилами, передбаченими КПК України, за участю сторони захисту. Однак законодавець не визначив, кому треба надати вилучені речі й документи, хто саме має складати протокол обшуку, кому він вручається тощо. Уважаємо, що вилучені речі й документи під час проведення обшуку за ініціативи сторони захисту повинні бути передані саме їй, оскільки в подальшому захисник повинен вирішувати, яким чином слід розпорядитися отриманими за його ініціативою об' єктами [8, с. 36-38].

Під час розслідування кримінальних правопорушень інколи виникає потреба проведення обшуку житла адвоката чи приміщень, де він здійснює адвокатську діяльність, під час якого нерідко допускають непоодинокі випадки порушення професійних прав адвоката. Ця проблема настільки складна, що вона наразі знайшла своє відображення в рішеннях Європейського суду з прав людини (ЄСПЛ). Цей Суд перевіряє, як діяли гарантії здійснення адвокатської діяльності в конкретних розглянутих справах відповідно до ефективних дій проти зловживань або свавілля, закріплених національним законодавством. Елементами, прийнятими до уваги ЄСПЛ, є тяжкість злочину, у зв'язку з яким проводять обшук i вилучення, наявність отриманого рішення судді або особи, наділеної судовими повноваженнями, дослідження факту, чи проводиться згодом судова перевірка, чи є постанова заснованою на розумній підозрі, і чи є межі втручання розумно обмеженими. Зокрема, ЄСПЛ перевіряє спосіб проведення обшуку i, якщо йдеться про адвокатську контору - чи проводиться він у присутності незалежного спостерігача 3 юридичною освітою, який забезпечує недоторканність документів, предметів тощо, що відносять до професійної таємниці адвоката. ЄСПЛ бере також до уваги масштаби наслідків для роботи й репутації осіб, стосовно яких проводили обшук. Суд перевіряє відповідність процедур, установлених національними законодавствами Конвенції. Згідно з прецедентною практикою ЄСПЛ акцентує увагу на тому, що постанови про обшук повинні, наскільки це можливо, забезпечувати обмеження їхніх наслідків розумними межами [9, с. 78-82].

Зазвичай обшуки в адвоката проводять для відшукання та вилучення доказів, які можуть довести вину клієнта адвоката, а не самого адвоката. Відповідно до абзацу другого частини 2 статті 23 Закону України «Про адвокатуру та адвокатську діяльність» від 5 липня 2012 року № 5076-VI під час проведення обшуку чи огляду житла, іншого володіння адвоката, приміщень, де він здійснює адвокатську діяльність, тимчасового доступу до речей і документів адвоката має бути присутній представник ради адвокатів регіону [10]. Тому адвокатам треба зберігати в телефонній книзі мобільного телефону номер «гарячої лініі» Комітету із захисту прав адвокатів, або, у разі відсутності такого Комітету - самої ради адвокатів відповідного регіону, розміщений на їі офіційному сайті.

Якщо правоохоронці не повідомили або відмовляють у повідомленні раду адвокатів регіону про проведення обшуку в адвоката, ніхто не позбавляє його можливості зробити це самостійно. Водночас усі докази, які були вилучені під час проведення обшуку в адвоката без участі представника 
ради адвокатів відповідного регіону або належного підтвердження того, що правоохоронці завчасно іï повідомили про проведення обшуку, надалі можуть бути визнані недопустимими.

Саме для контролю дотримання гарантій адвокатської діяльності, зокрема під час проведення обшуку й були створені відповідні Комітети із захисту прав адвокатів. Для максимального дотримання гарантій адвокатської діяльності в адвоката має бути договір про оренду, користування, тощо відповідного приміщення, у якому він здійснює свою адвокатську діяльність. Надання правоохоронцям копії такого договору або іншого документа, що підтверджує право адвоката на приміщення, перед початком проведення обшуку дуже сильно звужує їм «поле для маневрів» [11].

Висновки. Як захисник, так і адвокат за чинним КПК України не є обов'язковими учасниками проведення обшуку. Але в разі їх запрошення 3 надання кваліфікованої юридичної допомоги для захисту прав та законних інтересів підозрюваного та інших осіб сторона обвинувачення зобов'язана допустити захисника - для участі в проведенні обшуку житла підозрюваного чи іншого його володіння, а адвоката - для участі в проведенні обшуку особи, попередньо перевіривши їх повноваження. Така неоднозначність вирішення питання щодо допуску захисника чи адвоката для участі в проведенні різних видів обшуку відповідно до частин 1, 5 статті 236 КПК України не сприяє однаковому тлумаченню випадків, коли на місце проведення обшуку має бути допущений захисник, а коли - адвокат. 3 огляду на зазначене обгрунтовано потребу внесення змін до абзацу другого частини 5 статті 236 КПК України в частині можливості участі під час обшуку особи не лише адвоката, а й захисника. Позитивне вирішення цього питання надасть реальну можливість погодження цієї норми 3 частиною 1 цієї ж статті КПК України, у якій ідеться про допуск на місце проведення обшуку як захисника, так і адвоката.

\section{Використані джерела:}

1. Мороз I. Роль і статус адвоката в кримінальному процесі. Юридичний вісник Украӥни. 2011. № 50. С. 13-15.

2. Головань I. В. До питання про поняття адвокатської діяльності. Адвокат. 2012. № 1 (136). С. 12-16.

3. Чайка Р. А. Участь захисника на досудовому слідстві: автореф. дис. ... канд. юрид. наук: 12.00.09. Харків, 2008. 19 с.

4. Мартовицька О. В. Процесуальний статус захисника на стадії досудового розслідування. Сучасні тенденції розвитку криміналістики та кримінального процесу. Харків, 2017. С. 294-296.

5. Кримінальний процесуальний кодекс України від 13.04.2012. Верховна Рада України. URL: https:/ / zakon3.rada.gov.ua/laws/show/4651-17/ print.

6. Иванов А. Н., Комиссаров В. И. Тактика обыска. Состояние и перспективы развития. Юридические записки: Расследование преступлений: Вопросы теории и практики. Вып. 7. Воронеж, 1997. С. 87-93. 
7. Островська М. Допуск адвоката до участі в проведенні обшуку // Legalans. 2016. URL: http://legalans.com/articles/publications/6783-dopuskadvokata-do-uchast-v-provedenn-obshuku.html].

8. Дульський О.Л. Ситуації щодо участі адвоката під час проведення обшуку. Правові реформи в Україні: реалії сьогодення: матеріали міжвузівської науковопрактичної конференції (Київ, 28 лист. 2018 р.). Київ: Нац. акад. внутр. справ, 2018. C. 36-38.

9. Погорецький М. А., Погорецький М. М. Гарантії адвокатської таємниці у рішеннях Європейського суду з прав людини та їх імплементаційний вплив на кримінальне процесуальне законодавство України і правозастосовну практику. Вісник кримінального судочинства . № 2/2016. С. 77-87.

10. Про адвокатуру та адвокатську діяльність: Закон України від 05 липня 2012 року № 5076-VI. Верховна Рада України. URL: https:/ / zakon.rada.gov.ua/laws.

11. Костянтин Пінчук. Обшук у адвоката: як захистити гарантії професійної діяльності. Листопад 20, 2017. URL: http:/ /loyer.com.ua/uk/9451-2/.

\section{Стаття надійшла до редколегї 18.01.2019}

Дульский А.Л., аспирант кафедры досудебного расследования Учебнонаучного института № 1 Национальной академии внутренних дел, адвокат (г. Харьков, Украина)

\section{Защитник как участник производства обыска}

В статье рассмотрены спорные вопросы участия защитника и адвоката при производстве обыска жилища или иного владения лица, а также обыска лица. Акцентировано внимание на ряд положений, направленных на обеспечение соблюдения прав и законных интересов участников обыска. Сформулирован ряд предложений по совершенствованию действующего Уголовного процессуального кодекса Украины в части процессуального урегулирования деятельности защитника-адвоката по предоставлению юридической помощи лицу при производстве обыска.

Ключевые слова: следственные (розыскные) действия, обыск жилища или иного владения лица, обыск лица, защитник, адвокат, подозреваемый, иной участник уголовного производства.

\section{Dulskyi O. Defender as a Participant of Carrying out the Search}

The article deals with the issues of determining the range of participants in the search from the positions of determining their procedural status, the type of search, initiation of its conduct, compulsory or optional participation in the search. The controversial issues of the participation of a defense counsel and a lawyer during a search of a home or other person's possession and search of a person are determined. In carrying out these actions almost always there is a significant restriction of the constitutional right to inviolability of a home or other possession of a person. The emphasis is on a number of provisions aimed at ensuring the protection of the rights and legitimate interests of searchers. The view expressed in the literature that the notion of «defender» and «lawyer» should be distinguished is supported. The cases when the lawyer acts in the procedural status of the defendant of the suspect is investigated, and when - he is actually an attorney who renders legal aid to a person whose procedural status is not defined. The attention is paid to the unsettled provisions, in particular: 1) conducting simultaneous searches of persons whose protection is carried out by one 
attorney; 2) conducting a search of the person opposite to the defense counsel; 3 ) extending the rights of a person who is not yet procedural in order to protect his rights and legitimate interests; 4 ) the regulation of the duty of the investigator to inform the defense counsel in advance of all subsequent procedural actions involving the suspect; 5) the determination of the time during which the defender must arrive at the place of the search; 6) fixing the voluntary refusal in the case of the participation of a defender during a search, 7) conducting a search on the initiative of the defense party. A number of proposals aimed at improving the current Criminal Procedural Code of Ukraine in the part of the procedural regulation of the activity of a lawyer-advocate on the provision of legal assistance to a person during a search are expressed. In particular, paragraphs 1 and 5 of Article 236 of the Criminal Procedural Code of Ukraine have been analyzed and it is proposed to add an addition to Part 5 of this Article of the Code. The content of the addendum is that the search of a person can be carried out not only in the presence of a lawyer or representative, but also a person's defense depending on the procedural status given to her.

The proposals are aimed at procedural settlement of the cases of the invitation of a lawyer or counsel to provide qualified legal assistance in order to protect the rights and lawful interests of the suspect and other persons who are being searched.

Key words: investigative (search) actions, search of a home or other person's possession, search of a person, defender, lawyer, suspect, other participant in criminal proceedings.

УДК 343.241

Epodeeb M.I.

кандидат юридичних наук, науковий співробітник науково-дослідної лабораторії з проблем попередження, припинення та розслідування злочинів територіальними органами Національної поліції України Луганського державного університету внутрішніх справ імені Е.О. Дідоренка (м. СєВєродонещьк, Україна)

\section{ПРАВОВЕ ЗАБЕЗПЕЧЕННЯ ДОКУМЕНТАЛЬНОГО КОНТРОЛЮ ЗА ОБІГОМ ЗБРОЇ ТА ВИБУХОВИХ МАТЕРІАЛІВ В УКРАЇНІ}

У статті розглянуто особливості документального обліку руху зброї та вибухових матеріалів у суспільстві, акцентовано увагу на значенні облікових та інших документів, що $є$ носіями інформації про поводження зі зброєю та вибуховими матеріалами різними суб'єктами, для організації контролю та розслідування правопорушень у цій сфері. Запропоновано класифікацію документів, які дають уявлення про суб'єктів поводження зі зброєю, рух зброї та вибухових матеріалів, їх використання (застосування).

Ключові слова: документальний облік руху зброї та вибухових матеріалів, контроль за використанням (застосуванням) зброї та вибухових матеріалів, поводження зі зброєю та вибуховими матеріалами.

Постановка проблеми. Суспільна небезпечність незаконного поводження зі зброєю та вибуховими матеріалами полягає в тому, що воно сприяє вчиненню злочинів із використанням зазначених предметів. Тому законодавством 